FITRAH Jurnal Kajian Ilmu-ilmu Keislaman

Vol. 04 No. 2 Desember 2018

e-ISSN : 2460-2345, p-ISSN: 2442-6997

Web: jurnal.iain-padangsidimpuan.ac.id/index.php/F

\title{
PENGARUH TEKNIK MOTIVASI GURU DAN METODE PEMBELAJARAN TERHADAP AKHLAK SISWA DI MTs. MA'ARIF ROUDLOTUT-THOLIBIN PURWOSARI METRO UTARA
}

\author{
MUHAMAD RUDI WIJAYA \\ Dosen STIS Darul Ulum Lampung Timur \\ rudiwijaya68@gmail.com
}

\begin{abstract}
Abstrak
Attitude is the soul from Islamic education, For the purpose of Islamic education is to educate people that having a generous attitude. Attitude is established through formal education in the learning process. So that a teacher is expected to deliver it to be maximized in any learning. The results showed that the technique prasurvei motivation and methods of learning had taken but there is an obligation on bad students.Through technical innovation is given by a tutor and methods of learning attitude optimally expected students could be achieved in full. Thus the purpose of learning for good. The study aimed to identify the technique teacher motivation for students, attitude the learning methods he continued to influence on this fact attitude as well as teacher motivation techniques and methods of learning attitude. Including the design of this research. quantitative research using multiple. the regression equation is linearPopulation in this study were those coming Madrasah Tsanawiyah Ma'arif Roudlotut Tholibin Purwosari south metro With the number of 136. The sampling technique uses proportional strataied sampling technique. With a sample of 29 students. Data collection in the study using questionnaire and documentation instruments. Based on the results of the data analysis, it was found that there was a significant influence of the teacher's motivation technique on student morals by $80.7 \%$ with a linear regression equation $\mathrm{Y}=7,866+0,957 \mathrm{X} 1$, the influence of learning methods on student morals is $71.1 \%$ with linear regression equations $\hat{Y}=5,861+$ $0,958 \mathrm{X}_{2}$, and the joint influence between motivation techniques and learning methods on student morals is $79.7 \%$ with linear regression equations $\hat{Y}=6,059+0,804\left(X_{1}\right)+0,179\left(X_{2}\right)$. This means that students will be better to minimize the moral motivation techniques conducted by teachers through the learning process carried out very good, so are. learning methods Moral students would be better off if the learning methods he continued. implemented and properly applied.
\end{abstract}

Keyword: Motivation techniques, A method of learning, Students attitude

\section{Abstrak}

Akhlak merupakan jiwa dari pendidikan Agama Islam, karena tujuan pendidikan Islam adalah mendidik manusia agar memiliki akhlak yang 
FITRAH Jurnal Kajian Ilmu-ilmu Keislaman

Vol. 04 No. 2 Desember 2018

mulia. Akhlak siswa dapat dibentuk melalui proses pembelajaran dalam pendidikan formal. Pendidik memiliki peranan penting dalam pembentukan akhlak siswa. Sehingga seorang guru diharapkan memberikan pembelajaran yang maksimal dalam setiap proses pembelajaran. Hasil prasurvei menunjukan bahwa penerapan teknik motivasi dan metode pembelajaran sudah diterapkan namun masih ada siswa yang berakhlak kurang baik. Melalui teknik motivasi yang diberikan oleh guru dan metode pembelajaran yang optimal diharapkan akhlak siswa dapat terbentuk dengan maksimal. Dengan demikian tujuan pembelajaran dapat tercapai baik. Penelitian ini bertujuan untuk mengetahui pengaruh teknik motivasi guru terhadap akhlak siswa, metode pembelajaran terhadap akhlak serta pengaruh secara bersamasama teknik motivasi guru dan metode pembelajaran terhadap akhlak. Desain penelitian ini termasuk jenis penelitian kuantitatif yang menggunakan persamaan regresi linear berganda. Populasi dalam penelitian ini adalah seluruh siswa Madrasah Tsanawiyah Ma'arif Roudlotut Tholibin Purwosari Metro Utara yang berjumlah 136 orang. Teknik pengambilan sample menggunakan teknik strata sampling (stratified sampling) proposional. Dengan sampel 29 siswa. Pengambilan data dalam penelitian menggunakan instrumen angket dan dokumentasi. Berdasarkan hasil analisis data diperoleh bahwa ada pengaruh yang signifikan kuat teknik motivasi guru terhadap akhlak siswa sebesar 80,7\% dengan persamaan regresi linear $\mathrm{Y}=7,866+0,957 \mathrm{X} 1$, pengaruh antara metode pembelajaran terhadap akhlak siswa sebesar $71,1 \%$ dengan persamaan regresi linear $\hat{Y}=5,861+0,958 \mathrm{X}_{2}$ dan pengaruh secara bersama antara teknik motivasi dan metode pembelajaran terhadap akhlak siswa sebesar $79,7 \%$ dengan persamaan regresi linear $\hat{Y}=6,059+0,804\left(\mathrm{X}_{1}\right)+$ $0,179\left(\mathrm{X}_{2}\right)$. Hal ini berarti bahwa akhlak siswa akan lebih baik apabila tekni motivasi yang dilakukan oleh guru melalui proses pembelajaran dilaksanakan secara baik, begitu juga dengan metode pembelajaran. Akhlak siswa akan lebih baik jika metode pembelajaran dilaksanakan dan diterapkan dengan baik.

Kata Kunci: Teknik Motivasi, Metode Pembelajaran, Akhlak Siswa

\section{PENDAHULUAN}

Manusia merupakan makhluk ciptaan Allah SWT yang paling sempurna, karena manusia dibekali akal dan fikiran yang tidak Allah berikan kepada makhluk hidup lainnya. Setiap individu mempunyai kemampuan untuk membedakan antara yang baik dan yang buruk, sehingga mampu menilai setiap tingkah laku dan tutur kata dari individu lainya.Dalam kehidupan umat Islam tingkah laku dan tutur kata dari setiap individu merupakan realisasi akhlak yang pada dasarnya merupakan ajaran dari Islam itu sediri. 
Rasulullah SAW selalu memberikan contoh dan nasihat kepada umatnya untuk senantiasa berakhlak mulia dan meninggalkan akhlak yang tercela. Sebagaimana firman Allah SWT dalam surah Al-Ahzab ayat 21;

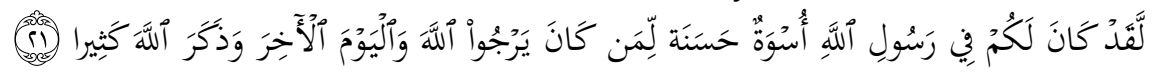

Artinya: Sesungguhnya telah ada pada (diri) Rasulullah itu suri teladan yang baik bagimu (yaitu) bagi orang yang mengharap (rahmat) Allah dan (kedatangan) hari kiamat dan Dia banyak menyebut Allah. ${ }^{1}$

Pada dasarnya tujuan pokok akhlak adalah agar setiap muslim berbudi pekerti, bertingkah laku, berperangai atau beradat istiadat yang baik sesuai dengan ajaran Islam. ${ }^{2}$ Oleh karena itu pendidikan akhlak harus diberikan kepada anak atau peserta didik sedini mungkin. Selain dari orang tua, pendidikan akhlak juga didapatkan dari para pendidik di lembaga pendidikan. Para pendidik memiliki peran yang sangat penting dalam pembentukan kepribadian peserta didiknya. Selain mengajarkan materi pelajaran pendidik juga harus memberi contoh yang baik dalam berprilaku dan bertutur kata.

Pendidikan agama lebih berorientasi pada belajar tentang agama, dan kurang berorientasi pada belajar bagaimana cara beragama yang benar. Akibatnya, terjadi kesenjangan antara pengetahuan dan pengamalan, antara gnosis dan praxis dalam kehidupan nilai agama. Dalam praktik, pendidikan agama berubah menjadi pengajaran agama sehingga tidak mampu membentuk pribadi-pribadi bermoral, padahal inti dari pendidikan agama adalah pendidikan moral. ${ }^{3}$

Hal tersebut sagat wajar karena pendidikan sesungguhnya memiliki misi yang amat mendasar yakni membentuk manusia utuh dengan akhlak sebagai salah satu indikator utama, generasi bangsa dengan karatekter akhlak mulia merupakan salah satu profil yang diharapkan dari praktik pendidikan nasional.

Pendidikan nasional berfungsi mengembangkan kemampuan dan membentuk watak serta peradaban bangsa yang bermartabat dalam rangka

${ }^{1}$ Departemen Agama RI, Al-Qur'an dan Terjemahnya (Bandung: CV Penerbit JART, 2005), hlm. 157.

${ }^{2}$ Rosihon Anwar, Akidah Akhlak (Bandung: Pustaka Setia, 2008), hlm. 211.

${ }^{3}$ Muhaimin, Pengembangan kurikulum pendidikan agama Islam: di sekolah, madrasah, dan perguruan tinggi (Jakarta: RajaGrafindo Persada, 2005), hlm. 23; Abdul Majid, Belajar dan Pembelajaran Pendidikan Agama Islam, Hasil penelitian Heyneman Dan Loxley (Bandung: PT Remaja Rosdakarya, 2012), hlm. 10. 
FITRAH Jurnal Kajian Ilmu-ilmu Keislaman

Vol. 04 No. 2 Desember 2018

mencerdaskan kehidupan bangsa bertujuan untuk berkembangnya potensi peserta didik agar menjadi manusia yang beriman dan bertakwa kepada Tuhan Yang Maha Esa, berakhlak mulia, sehat, berilmu, cakap, kreatif, mandiri dan menjadi warga negara yang demokratis serta bertanggung jawab. ${ }^{4}$

Sesuai dengan fungsi dan tujuan pendidikan nasional di atas, maka pembentukan sebuah karakter memang sangat diperlukan, akhlak mejadi dasar yang harus ditanamkan sejak dini melalui proses pembelajaran. Hal tersebut merupakan tugas dan tanggung jawab seorang pendidik untuk memberikan bekal tersebut kepada peserta didiknya. Pendidik dapat menanamkan akhlak terhadap peserta didiknya melalui suri tauladan yang baik. Hasil penelitian menunjukkan bahwa 34\% mutu pendidikan dipengaruhi oleh faktor guru (di negara maju 36\%).Dibandingkan dengan faktor pengelolaan $22 \%$, sarana fisik $26 \%$, dan waktu belajar $18 \% .5$

Kenyataan di lapangan menunjukkan terdapat berbagai masalah yang berkaitan dengan kondisi guru, antara lain: 1) adanya keragaman kemampuan dalam proses pembelajaran dan penggunaan pengetahuan; 2) belum adanya alat ukur yang akurat untuk mengetahui kemampuan guru; 3) pembinaan yang dilakukan belum mencerminkan kebutuhan; 4) kesejahteraan guru yang belum memadai. ${ }^{67}$

Pendidik menginginkan peserta didiknya berakhlak yang baik, memberikan segenap kemampuannya dalam melaksanakan proses pembelajaran. Seperti halnya peserta didik yang mampu menerapkan segala apa yang diperolehnya direalisasikan dalam kehidupan sehari-hari. Bagaimana tingkah lakunya diterapkan dalam kehidupannya, seperti halnya hubungannya dengan Allah, hubungannya dengan sesamanya dan hubungannya dengan alam sekitar. Inilah yang menjadi dasar pentingnya akhlak dalam kehidupan. Sebagaimana Firman Allah SWT dalam surah al-A'raf ayat 199;

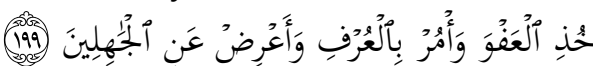

${ }^{4}$ Dewan Perwakilan Rakyat Republik Indonesia dan Presiden RI, Undang-undang Republik Indonesia Nomor 20 tahun 2003 tentang Sistem Pendidikan Nasional (Bandung: Fokus Media, 2006).

${ }^{5}$ Hasil penelitian Heyneman Dan Loxley dalam Abdul Majid, Belajar dan Pembelajaran Pendidikan Agama Islam, hlm. 5-6.

${ }^{6}$ Depdiknas, (2003:1) dalam Abdul Majid, Belajar dan Pembelajaran Pendidikan Agama Islam, h. 6

7 dewan Perwakilan Rakyat Republik Indonesia dan Presiden Republik Indon, Undang-undang Republik Indonesia Nomor 20 tahun 2003 tentang Sistem Pendidikan Nasional. 
Artinya: jadilah Engkau Pema'af dan suruhlah orang mengerjakan yang ma'ruf, serta berpalinglah dari pada orang-orang yang bodoh ${ }^{8}$

Selain itu, kelemahan dari pendidikan agama Islam di sekolah, baik dalam pemahaman materi pendidikan agama Islam maupun dalam pelaksanaanya, yaitu: (1) dalam bidang teologi, ada kecenderungan mengarah pada paham fatalistik; (2) bidang akhlak yang berorientasi pada urusan sopan santun dan belum dipahami sebagai keseluruhan pribadi manusia beragama; (3) bidang ibadah diajarkan sebagai kegiatan rutin agama dan kurang ditekankan sebagai proses pembentukan kepribadian; (4) dalam bidang hukum (fiqih) cenderung dipelajari sebagai tata aturan yang tidak akan berubah sepanjang masa, dan kuranh memahami dinamika dan jiwa hukum Islam; (5) agama Islam cenderung diajarkan sebagai dogma dan kurang mengembangkan rasionalitas serta kecintaan pada kemajuan ilmu pengetahuan; (6) orientasi mempelajari AlQuran masih cenderung pada kemampuan membaca teks, belum mengarah pada pemahaman arti dan penggalian makna. ${ }^{9}$

Pembelajaran Agama Islam memuat ajaran tentang tata hidup yang meliputi seluruh aspek kehidupan manusia, maka pengajaran agama Islam sebenarnya harus berarti pengajaran tentang tata hidup yang berisi pedoman pokok yang akan digunakan oleh manusia dalam menjalani kehidupannya di dunia ini untuk menyiapkan kehidupan yang sejahtera di akhirat nanti ${ }^{10}$. Dalam proses pembelajaran, termasuk pembelajaran pendidikan agama setidaknya terdapat tiga komponen utama yang saling berpengaruh. Ketiga komponen tersebut adalah: (1) kondisi pembelajaran; (2) metode pembelajaran;(3) hasil pembelajaran. ${ }^{11}$

Banyak kalangan menilai bahwa metode pembelajaran agama Islam yang berjalan saat ini masih sebatas transfer nilai dengan pendekatan hafalan. Metode pembelajaran yang berlaku saat ini masih bersifat klasik, dalam arti mewariskan sejumlah materi ajaran agama yang diyakini benar untuk disampaikan kepada

${ }^{8}$ Departemen Agama RI, Al-Qur'an dan Terjemahnya, hlm. 423.

9 Andi Rasdijanah, Butir-Butir Pengarahan Dirjen Bimbaga Islam pada Acara Pelatihan Peningkatan Wawasan Ilmu Pengetahuan dan Kependidikan Bagi Dosen Pendidikan Agama Islam padaPerguruan Tinggi Umum (Bandung: Dirjen Bimbingan Islam, 1995), hlm. $4-7$.

${ }^{10}$ Zakiah Daradjat, Metodik khusus pengajaran agama Islam (Jakarta: Bumi Aksara, 1995), hlm. 60.

${ }^{11}$ Ahmad Munjin Nasih dan Lilik Nur Kholidah, Metode dan Teknik Pembelajaran Pendidikan Agama Islam (Bandung: PT.Refika Aditama, 2013), hlm. 19. 
FITRAH Jurnal Kajian Ilmu-ilmu Keislaman

Vol. 04 No. 2 Desember 2018

anak didik tanpa memberikan kesempatan kepada mereka agar menyikapi materi-materi tersebut secara kritis, mengoreksi, mengevaluasi dan mengomentarinya. ${ }^{12}$

Pembelajaran agama Islam di lembaga pendidikan formal tidak hanya sekedar mengajarkan ilmu agama kepada peserta didik, tetapi juga menanamkan komitmen terhadap ajaran agama yang dipelajarinya. Hal ini berarti bahwa pendidikan agama memerlukan pendekatan pengajaran agama yang berbeda dari pendekatan subjek pelajaran yang lain. Sebab disamping mencapai penguasaan terhadap seperangkat ilmu agama, pendidikan agama juga menanamkan komitmen kepada anak didik untuk mau mengamalkannya. ${ }^{13} \mathrm{Hal}$ tersebut menyebutkan bahwa, proses pembelajaran harus dilaksanakan secara efektif dan efisien oleh seorang pendidik, sehingga apa yang menjadi tujuan pembelajaran akan tercapai, seperti halnya pendidikan agama Islam. Akhlak yang nantinya menjadi tingkah laku kebiasaan seorang peserta didik dapat terealisasi tanpa adanya suatu pengaruh dari yang lain. Menjadi motivasi pada diri siswa yang dibawa dari proses pembelajaran yang baik dari seorang pendidik.

Hasil prasurvei di peroleh bahwa Teknik Motivasi Guru sudah dilakukan, namun masih belum terealisasi dengan baik, hal ini ditunjukan dengan guru kurang memperhatikan bahwa dirinya adalah suri tauladan, yang nantinya akan menjadi panutan bagi siswa siswinya. Seperti gaya berbicara dengan siswa, dengan guru, bahkan dengan orang lain. Serta guru yang kurang memberikan motivasi berupa pujian baik kata maupun tidakan kepada peserta didik, sehingga peserta didik kurang termotivasi dalam proses pembelajaran.

Pemahaman pendidik tentang penerapan motivasi dan metode pembelajaran yang digunakan berdampak pada kurangnya pemahaman siswa dalam menyerap materi yang diajarkan serta merealisasikan dalam kehidupan sehari hari.Hal itu di tunjukan dengan siswa yang kurang disiplin, kurang hormat terhadap guru, lalai dalam melaksanakan tugas sampai tidak mau mengerjakan tugas.Kurangnya pemahaan siswa ini membawa tujuan pembelajran yang tidak tercapai, apalagi mata pelajaran pendidikan agama Islam hlm. 32.

${ }_{12}$ Mastuhu (2002) dalam Nasih dan Kholidah Metode dan Teknik Pembelajaran..., ${ }^{13}$ Nasih dan Kholidah Metode dan Teknik Pembelajaran..., hlm. 33. 
yang nantinya mengakumulasi tentang pengetahuan dan sikap yang sesuai dengan ajaran Islam itu sendiri. ${ }^{14}$

Berdasarkan uraian di atas, peneliti ingin meneliti lebih jauh mengenai tingkat pengaruh motivasi dan metode pembelajaran yang dilaksanakan dalam proses pembelajaran terhadap akhlak siswa di MTs Ma'arif Roudhotuttholibin, Purwosari, Metro Utara.

\section{KAJIAN LITERATUR}

\section{Eksistensi Akhlak}

Kata "akhlak" berasal dari bahasa Arab, yaitu jama' dari kata "khuluqun" yang secara linguistik diartikan dengan budi pekerti, perangai, tingkah laku atau tabiat, tata krama, sopan santun, adab dan tindakan. Kata "akhlak" juga berasal dari bahasa kata "khalaqa" atau "khalqun", artinya kejadian, serta erat hubungannya dengan "khaliq", artinya pencipta dan "makhluq", artinya menciptakan. ${ }^{15}$

Akhlak merupakan sifat yang tertanam dalam jiwa yang mendorongnya untuk melakukan perbuatan tanpa memerlukan pemikiran dan pertimbangan. ${ }^{16}$ Selain itu akhlak adalah sifat yang tertanam dalam jiwa yang menimbulkan macam-macam perbuatan dengan gamblang dan mudah, tanpa memerlukan pemikiran dan pertimbangan. ${ }^{17}$ Yang timbul dari dalam diri orang yang mengerjakannya tanpa ada paksaan atau tekanan dari luar.Perbuatan akhlak adalah perbuatan yang dilakukan atas dasar kemauan, pilihan dan keputusan yang bersangkutan. ${ }^{18}$

Pendidikan akhlak memiliki ruang yang cukup luas baik dalam keluarga masyarakat maupun lingkup pendidikan formal. Ruang lingkup akhlak dalam Islam meliputi semua aktivitas manusia dalam segala bidang hidup dan kehidupan. ${ }^{19}$

${ }^{14}$ Hasil Prasurvei melalui Observasi di MTs Ma'ari Roudhotut Tholibin, Purwosari, Metro Utara 13 Februari 2015

${ }^{15}$ Beni Ahad Saebani dan Abdul Hamid, Ilmu Akhlak (Bandung: Pustaka Setia, 2010), hlm. 2.

${ }^{16}$ Ibn Miskawaih dalam Beni Ahad Saebani, Abdul Hamid, dan M. Yatimin, Studi Akhlak Dalam Perspektif Islam (Jakarta: Amzah, 2007), hlm. 14.

${ }^{17}$ Imam Al-Ghazali dalam Saebani dan Hamid, Ilmu Akhlak... hlm. 14.

${ }^{18}$ Saebani dan Hamid, hlm. 15.

19 Muhammad Daud Ali, Pendidikan Agama Islam (Jakarta: PT. Raja Grafindo Persada, 2011), hlm. 351. 
FITRAH Jurnal Kajian Ilmu-ilmu Keislaman

Vol. 04 No. 2 Desember 2018

Adapun pokok-pokok ajaran ilmu akhlak ialah segala perbuatan manusia yang timbul dari orang yang melaksanakan dengan sadar, disengaja dan ia mengetahui waktu melakukannya, akibat dari apa yang dia perbuatan. Demikian pula perbuatan yang tidak dengan kehendak tetapi dapat diikhtiarkan penjagaannya pada waktu sadar. ${ }^{20}$

\section{Teknik Motivasi Guru}

Setiap proses belajar mengajar biasanya untuk meningakatkan intensitas proses belajar mengajar guru menggunakan teknik motivasi, tidak terkecuali dalam pelaksanaan pembelajaran.Teknik adalah cara yang dilakukan seseorang dalam rangka mengimplementasikan suatu metode. ${ }^{21}$ Sedangkan motivasi berpangkal dari kata "motif", yang dapat diartikan sebagai daya upaya yang mendorong seseorang untuk melakukan sesuatu.Berawal dari kata "motif" itu, maka motivasi dapat diartikan sebagai daya penggerak yang telah menjadi aktif. 22

Motivasi merupakan dorongan yang terdapat pada diri seseorang untuk dapat mengadakan perubahan tingkah laku yang baik dalam memenuhi kebutuhannya. ${ }^{23}$ Senada dengan itu motivasi adalah usaha yang disadari oleh pihak guru untuk menimbulkan motif-motif pada diri murid yang menjunjung kegiatan kearah tujuan-tujuan belajar" ${ }^{24}$

Seorang pendidik harus melaksanakan motivasi secara efektif dalam proses pembelajaran baik dalam bentuk dorongan dari dalam mauun dari luar demi tercapainya tujuan yang hendak di capai, khususnya penerapan pembelajaran pendidikan agama Islam.

Motivasi sangat diperlukan dalam proses kegiatan pembelajaran pendidik terhadap peserta didik. Sebab seorang yang tidak mempunyai motivasi dalam belajar, tidak akan mungkin melakukan aktivitas belajar. Apalagi dapat mendorong seseorang untuk terbiasa melakukan perbatan baik dalam kehidupan sehari-hari. Motivasi dibagi menjadi 2 yaitu:

${ }^{20}$ Ali, Pendidikan Agama..., hlm. 12.

${ }^{21}$ Hamzah B. Uno, Teori Motivasi dan Pengukurannya (Jakarta: Bumi Aksara, 2006), hlm. 19.

22 Sardiman A.M, Interaksi \& Motivasi Belajar Mengajar (Jakarta: Raja Grafindo Persada, 2011), hlm. 73.

${ }^{23}$ B. Uno, Teori Motivasi dan Pengukurannya..., hlm. 3.

${ }^{24}$ Daradjat, Metodik khusus pengajaran ...., hlm. 140. 
1) Motivasi instrinsik, jenis motivasi ini timbul dari dalam diri individu sendiri tanpa ada paksaan dorongan orang lain, tetapi atas dasar kemauan sendiri.

2) Motivasi ekstrinsik, jenis motivasi ini timbul sebagai akibat pengaruh dari luar individu, apakah karena adanya ajakan, suruhan, atau paksaan dari orang lain sehingga dengan keadaan demikian siswa mau melakukan sesuatu atau belajar. ${ }^{25}$

Beberapa teknik motivasi yang dapat dilakukan dalam pembelajaran sebagai berikut: ${ }^{26}$

1. Pernyataan penghargaan secara verbal.

2. Menggunakan nilai ulangan sebagai pemacu keberhasilan.

3. Menimbulkan rasa ingin tahu. Rasa ingin tahu merupakan daya untuk meningkatkan motif belajar siswa.

4. Memunculkan sesuatu yang tidak diduga oleh siswa.

5. Menjadikan tahap dini dalam belajar mudah bagi siswa.

6. Menggunakan materi yang dikenal siswa sebagai contoh dalam belajar.

7. Gunakan kaitan yang unik dan tak terduga untuk menerapkan suatu konsep dan prinsip yang telah dipahami.

8. Menuntut siswa untuk menggunakan hal-hal yang telah dipelajari sebelumnya.

9. Menggunakan simulasi dan permainan.

10. Memberi kesempatan kepada siswa untuk memperlihatkan kemahirannya di depan umum.

11. Mengurangi akibat yang tidak menyenangkan dan tidak keterlibatan siswa dalam kegiatan belajar.

12. Memahami iklim sosial dalam sekolah.

13. Memanfaatkan kewibawaan guru secara tepat.

14. Memperpadukan motif-motif yang kuat.

15. Memperjelas tujuan belajar yang hendak dicapai.

16. Merumuskan tujuan-tujuan sementara.

17. Memberitahukan hasil kerja yang telah dicapai.

18. Membuat suasana persaingan yang sehat di antara para siswa.

${ }^{25}$ Pupuh Fathurrohman dan M. Sobry Sutikno, Strategi Belajar Mengajar Melalui Penanaman Konsep Umum \& Konsep Islami (Bandung: Refika Aditama, 2010.), hlm. 19.

${ }^{26}$ B. Uno, Teori Motivasi dan Pengukurannya, hlm. 35-37. 
FITRAH Jurnal Kajian Ilmu-ilmu Keislaman

Vol. 04 No. 2 Desember 2018

19. Mengembangkan persaingan dalam diri sendiri.

20. Memberikan contoh yang positif.

\section{Metode Pembelajaran}

Metode berasal dari bahasa latinmeta yang berarti melalui, dan hodos yang berarti jalan ke atau cara. Dalam bahasa arab, metode disebut tariqah, artinya jalan, cara, sistem atau ketertiban dalam mengerjakan sesuatu. Menurut istilah, metode ialah suatu sistem atau cara yang mengatur suatu cita-cita. ${ }^{27}$ Metode mengajar dapat diartikan sebagai cara yang dipergunakan oleh pendidik dalam mengadakan hubungan dengan peserta didik pada saat berlangsungnya proses pembelajaran. ${ }^{28}$ Metode adalah $a$ way achieving something "cara untuk mencapai sesuatu"..$^{29}$

Metode pembelajaran merupakan salah satu strategi pembelajaran yang dapat dilakukan oleh guru untuk menghadapi masalah dalam proses pembelajaran sehingga pencapaian tujuan pengajaran dapat tercapai dengan baik. Dengan pemanfaatan metode yang efektif dan efisien, guru akan mampu mencapai tujuan pengajaran.

Metode mengajar memegang peranan penting dalam mencapai tujuan atau keberhasilan pengajaran. Seorang guru akan berhasil dalam tugas mengajar, bila dengan metode atau teknik yang digunakannya ia mampu memotivasi serta memancing daya dan gairah belajar murid-muridnya. ${ }^{30}$

Dalam proses pendidikan agama Islam, khususnya pendidikan akhlak terdapat beberapa metode yang sering digunakan oleh pendidikan dalam menanamkan akhlak pada peserta didik. Namun tidak terlepas dari metode pembelajaran pendidikan agama Islam. Karena metode saling terkait satu sama lain dan saling melengkapi, khususnya dalam hal penerapan akhlak dalam

27 TB. Aat Syafaat, Peranan pendidikan Agama Islam dalam mencegah kenakalan remaja (juvenile deliquency) (Jakarta: Rajawali Pers (Rajagrafindo Persada), 2008), hlm. 39.

${ }^{28}$ H. Ramayulis, Metodologi pendidikan agama Islam (Jakarta: Kalam Mulia, 2010), hlm. 3.

${ }^{29}$ James R. Davis, Teaching Strategies for the College Classroom (Westview Press, 1976); Majid, Belajar dan Pembelajaran Pendidikan Agama Islam, hlm. 131.

30 Omar Mohammad Al- Toumy Al Syabany, Falsafah Pendidikan Islam, (terjemahan Hasan Langgulung dari Falsafah al- Tarbiyah al- Islamiyyah), cet. 2 (Jakarta: Bulan Bintang, 1979), hlm. 589; Ramayulis, Metodologi pendidikan agama Islam, hlm. 9-11. 
kehidupan sehari-hari. Pada dasarnya metode pendidikan Islam secara formal yaitu: ${ }^{31}$

1. Metode Induksi (pengambilan kesimpulan).

2. Metode perbandingan.

3. Metode Kuliah.

4. Metode Dialog dan Perbincangan.

5. Metode Halaqah.

6. Metode Riwayat.

7. Metode Mendengar.

8. Metode Membaca.

9. Metode Imla'.

10. Metode Hafalan.

11. Metode Pemahaman.

12. Metode lawatan untuk menuntut (Pariwisata).

Berdasarkan kutipan di atas, metode pembelajaran sangatlah banyak. Dalam pnggunaannya seorang guru harus memilih mana yang akan digunakan dalam proses pembelajaran, dengan menimbang materi yang akan diajarkan.

\section{Kerangka Berfikir}

“Kerangka pemikiran (kerangka pikir) merupakan penjelasan sementara terhadap gejala yang terjadi objek permasalahan dalam penelitian." ${ }^{2}$ Dengan demikian kerangka berpikir penulis dalam penelitian adalah Apakah pengaruhTeknik Motivasi Guru dan Metode Pembelajaran terhadapAkhlak siswa di MTs. Ma'arif Roudlotuttholibin, Purwosari, Metro Utara. Paradigma adalah pola pikir yang menunjukkan pengaruh variabel yang akan diteliti yang sekaligus mencerminkan jenis dan jumlah rumusan masalah yang perlu dijawab melalui penelitian, teori yang digunakan untuk merumuskan hipotesis, jenis dan jumlah hipotesis, dan teknik analisis statistik yang akan digunakan. ${ }^{33}$ Dengan demikian penulis kemukakan paradigma dalam penelitian ini adalah sebagai berikut:

${ }^{31}$ Samsul Nizar, Filsafat Pendidikan Islam, Pendekatan Historis, Teoritis dan Praktis, cet. ke-1 (Jakarta: Ciputat Pers, 2002), hlm. 74.

32 Suharsimi Arikunto, Prosedur Penelitian: Suatu Pendekatan Praktik (Jakarta: Rineka Cipta, 2013), hlm. 57.

33 Sugiyono, Metode Penelitian Pendidikan, Pendekatan Kualitatif, Kuantitatif, dan RED (Bandung: Alfabeta, 2009), hlm. 42. 
FITRAH Jurnal Kajian Ilmu-ilmu Keislaman

Vol. 04 No. 2 Desember 2018

Gambar 2.1.Tentang Pengaruh Teknik Motivasi Guru dan Metode Metode Pembelajaran terhadapAkhlak Siswa

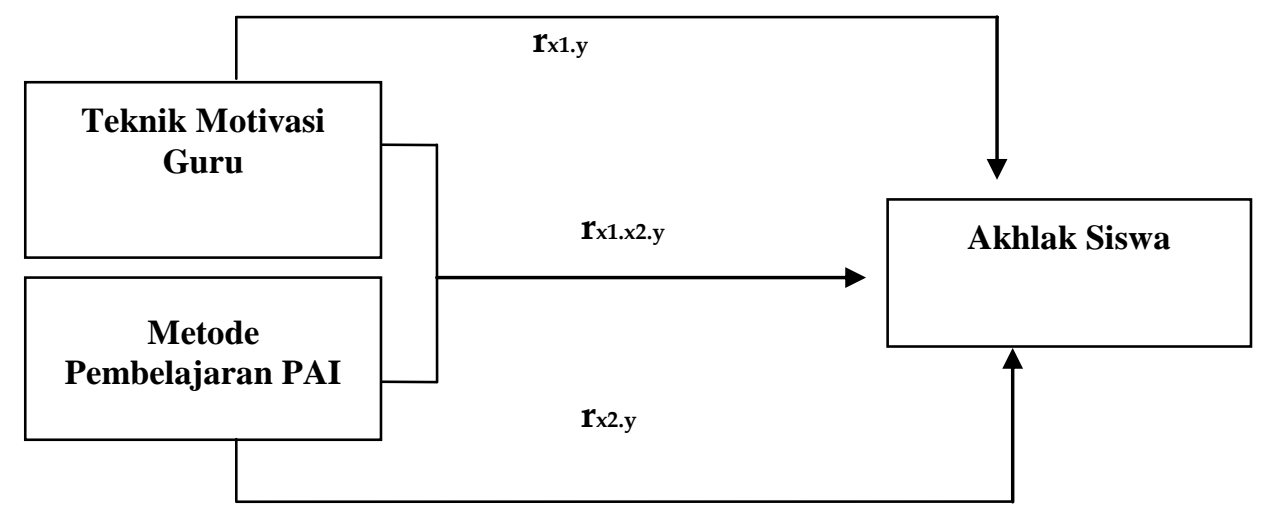

\section{Rumusan Hipotesis}

Hipotesis adalah "jawaban sementara terhadap masalah penelitian, yang kebenarannya masih harus diuji secara empiris". ${ }^{34}$ Dengan demikian dapat dipahami hipotesis adalah dugaan yang bersifat sementara yang mungkin benar dan mungkin salah. Dugaan sementara yang peneliti rumuskan adalah sebagai berikut;

Ha :

a. Ada pengaruh antara Teknik Motivasi Guruterhadap akhlak siswa di MTs.Ma' arifRoudlotuttholibin, Purwosari, Metro Utara

b. Ada pengaruh antara Metode Pembelajaran terhadap akhlak siswa di MTs.Ma'arifRoudlotuttholibin, Purwosari, Metro Utara

c. Ada pengaruh antara Teknik Motivasi Guru dan Metode Pembelajaran terhadap akhlak siswa di MTs.Ma'arifRoudlotuttholibin, Purwosari, Metro Utara.

\section{METODE PENELITIAN}

Penelitian ini adalah penelitian kuantitafif. Pengumpulan dan penganalisisan dengan menggunakan data angka dengan pendekatan dedukatifverifikatif. ${ }^{35}$ Penelitian bersifat korelasional yang bertujuan mendeteksi sejauh mana variasi-variasi pada suatu faktor berkaitan dengan variasi-variasi hlm. 21.

${ }^{34}$ Sumadi Suryabrata, Metode Penelitian (Jakarta: Raja Grafindo Persada, 2008), ${ }^{35}$ S. Nasution, Metode Research (Jakarta: Bumi Aksara, 2000.), hlm. 23. 
pada satu atau lebih satu faktor berdasarkan koefisien korelasi."36 Data diolah dengan metode statistika" ${ }^{\prime 37}$. Populasi adalah seluruh siswa di MTs.Ma'arif Roudlotut Tholibin, Purwosari, Metro Utara berjumlah 136 siswa. Prinsip penarikan sampel dengan probability sampling dengan teknik strata sampling. ${ }^{38}$ jumlah sampel diambil dari setiap strata sebanding, sesuai dengan proporsi dan ukuran. Teknik pengumpulan data dalam penelitian ini adalah 1) Metode Queisioner (Angket). ${ }^{39}$ Juga sejumlah daftar pertanyaan yang dikirim kepada responden". ${ }^{40}$ Angket digunakan mengenai proses Metode Pembelajaran, Motivasi dan akhlak siswa. 2). Metode Wawancara; ${ }^{41}$ 3)Metode Dokumentasi yakni metode yang digunakan untuk memperoleh informasi dari sumber tertulis atau dokumen-dokumen, baik berupa buku-buku, majalah, peraturanperaturan, notulen rapat, catatan harian dan sebagainya. ${ }^{42}$

\section{HASIL PENELITIAN DAN PEMBAHASAN}

Hipotesis penelitian yang berbunyi "Ada pengaruh Teknik Motivasi terhadap Akhlak Siswa MTs.Ma'arifRoudlotut-Tholibin" model pengaruhnya dinyatakan dalam bentuk persamaan regresi $\mathrm{Y}=7,866+0,957$ X1.Uji pengaruh motivasi terhadap Akhlak Siswa MTs.Ma'arifRoudlotut-Tholibin dan linieritas persamaan regresi dapat disajikan sebagai berikut.

Tabel 4.18

Uji Pengaruh Teknik Motivasi Guru terhadap Akhlak Siswa

\section{Model Summary ${ }^{b}$}

\begin{tabular}{cccccc} 
& & & & Change Statistics \\
Model & $\mathrm{R} \quad$ Square & R Square & Sig. F \\
\hline
\end{tabular}

${ }^{36}$ Suharsimi Arikunto, Prosedur Penelitian Suatu Pendekatan Praktek, (Jakarta: Rineka Cipta, 2006),h. 124

${ }^{37}$ Arikunto, Prosedur Penelitian: Suatu Pendekatan Praktik, hlm. 125.

38 Syofian Siregar, Statistik Parametrik untuk Penelitian Kuantitatif (Jakarta: Bumi Aksara, 2013), hlm. 57.

${ }^{39}$ Anas Sudijono, Pengantar Statistik Pendidikan (Jakarta: Rajawali Pers, 2010), hlm. 30.

${ }^{40}$ W. Gulo, Metodologi Penelitian (Jakarta: PT. Gramedia Widia Sarana Indonesia, 2002.), hlm. 111.

${ }^{41}$ Arikunto, Prosedur Penelitian: Suatu Pendekatan Praktik, hlm. 155.

${ }^{42}$ Arikunto, hlm. 119. 
FITRAH Jurnal Kajian Ilmu-ilmu Keislaman

Vol. 04 No. 2 Desember 2018

$\begin{array}{llllllllll}1 & .898^{\mathrm{a}} & .807 & .800 & 3.652 & .807 & 112.794 & 1 & 27 & .000\end{array}$

a. Predictors: (Constant), Motivasi

b. Dependent Variable: Akhlak

Tabel tersebut menunjukan bahwa pengaruh teknik Teknik Motivasi Guru terhadap akhlak siswa sangat kuat positif, yang ditunjukan pada nilai $r=$ 0,898 . Arti dari pengaruh positif yakni jika penerapan motivasi ditingkatkan maka akan mempengaruhi nilai akhlak siswa yang positif atau sebaliknya semakin menurun tingkat pemberian Teknik Motivasi Guru kepada siswa maka akan menirunkan akhlak siswa. Adapun kontribusi yang diberikan Teknik Motivasi Guru terhadap akhlak siswa adalah sebesar 80,7\% yang dilihat dari nilai R Square.

Tabel 4.19

Uji Pengaruh Teknik Motivasi Guru terhadap Akhlak Siswa

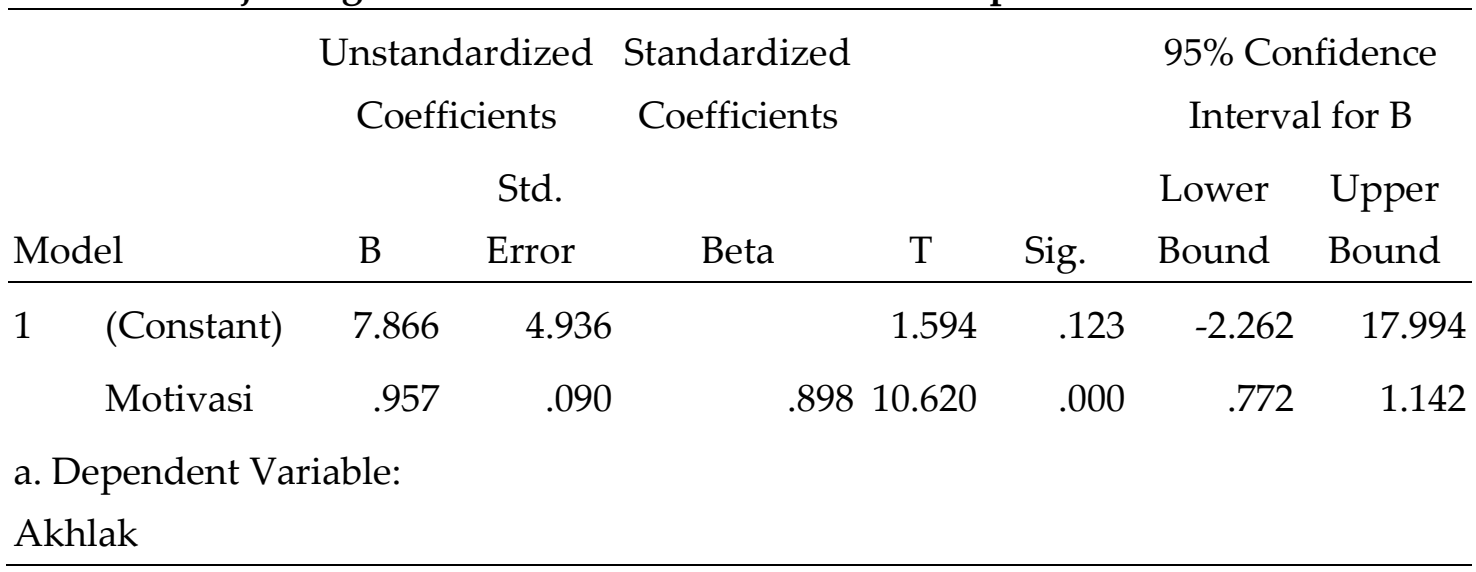

Berdasarkan table Coefficients di atas, dapat dilihat bahwa nilai koefisien yang digunakan untuk memperkirakan pengaruh dari variabel tersebut adalah sebesar 0,957 dan konstan 7,866. Dengan demikian persamaan yang terbentuk dari variabel trsebut adalah $\mathrm{Y}=7,866+0,957 \mathrm{X} 1$ di mana $\mathrm{Y}$ adalah Akhlak siswa sedangkan X1 Adalah Motivasi yang dilakukan oleg guru. Sedangkan sebaran data dapat dilihat dari histogram dan gambar sebaran plot dibawah ini. 
Gambar. 4.2

Histogram Pengaruh Motivas Terhadap Akhlak Siswa

Histogram

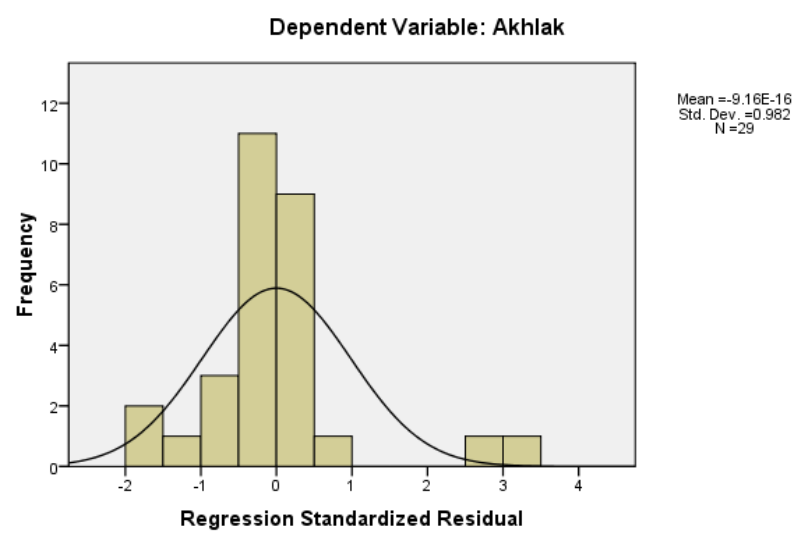

Gambar. 4.3

Plot atau Sebaran Data Pengaruh Motivas Terhadap Akhlak Siswa

Normal P-P Plot of Regression Standardized Residual

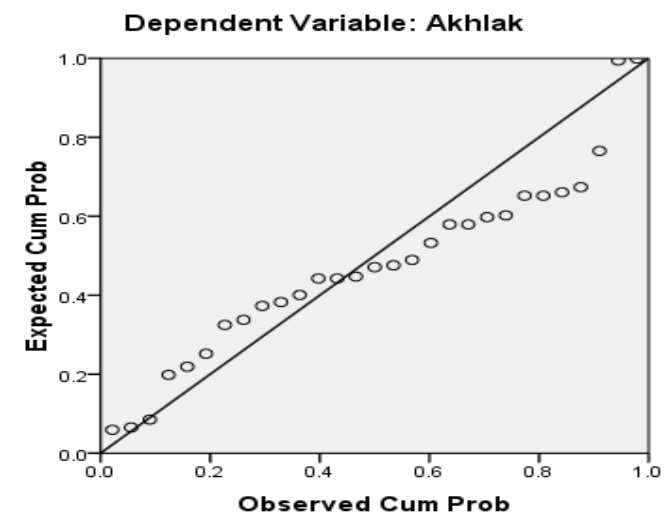

Pengaruh Metode Pembelajaran $\left(X_{2}\right)$ Terhadap Akhlak Siswa(Y) PAI MTs.Ma'arifRoudlotut-Tholibin (Y)

Hipotesis yang berbunyi "Ada pengaruh Metode Pembelajaran Terhada Akhlak Siswa MTs.Ma'arifRoudlotut-Tholibin". Model pengaruh Metode Pembelajaran Terhada Akhlak Siswa MTs.Ma'arifRoudlotut-Tholibin dinyatakan dalam bentuk persamaan regresi $\hat{Y}=5,861+0,958 \mathrm{X}_{2}$. 
FITRAH Jurnal Kajian Ilmu-ilmu Keislaman

Vol. 04 No. 2 Desember 2018

Tabel 4.20

Uji pengaruh Metode Pembelajaran Terhadap Akhlak Siswa MTs.Ma'arif Roudlotut-Tholibin.

\begin{tabular}{|c|c|c|c|c|c|c|c|c|c|}
\hline \multirow[b]{3}{*}{ Model } & \multirow[b]{3}{*}{$\mathrm{R}$} & \multirow{3}{*}{$\begin{array}{c}\mathrm{R} \\
\text { Square }\end{array}$} & \multirow{3}{*}{$\begin{array}{c}\text { Adjuste } \\
\text { d R } \\
\text { Square }\end{array}$} & \multirow{3}{*}{$\begin{array}{l}\text { Std. Error } \\
\text { of the } \\
\text { Estimate }\end{array}$} & \multicolumn{5}{|c|}{ Change Statistics } \\
\hline & & & & & R Square & $\mathrm{F}$ & & & Sig. F \\
\hline & & & & & Change & Change & df1 & df2 & Change \\
\hline 1 & $.843^{\mathrm{a}}$ & .711 & .700 & 4.467 & .711 & 66.457 & & 2 & .000 \\
\hline \multicolumn{10}{|c|}{ a. Predictors: (Constant), Metode } \\
\hline \multicolumn{10}{|c|}{ b. Dependent Variable: Akhlak } \\
\hline
\end{tabular}

Tabel 4.21

Uji pengaruh Metode Pembelajaran Terhadap Akhlak Siswa MTs.Ma'arif Roudlotut-Tholibin.

\begin{tabular}{|c|c|c|c|c|c|c|c|c|}
\hline \multirow[b]{2}{*}{ Model } & & $\begin{array}{l}\text { Unstandardized } \\
\text { Coefficients } \\
\text { Std. }\end{array}$ & $\begin{array}{l}\text { rdized } \\
\text { ents }\end{array}$ & \multirow[t]{2}{*}{$\begin{array}{l}\text { Coefficient } \\
\text { s }\end{array}$} & \multirow[b]{2}{*}{$\mathrm{T}$} & \multirow[b]{2}{*}{ Sig. } & \multicolumn{2}{|c|}{$\begin{array}{l}\text { 95\% Confidence } \\
\text { Interval for B }\end{array}$} \\
\hline & & B & $\begin{array}{l}\text { Std. } \\
\text { Error }\end{array}$ & & & & $\begin{array}{l}\text { Lower } \\
\text { Bound }\end{array}$ & $\begin{array}{l}\text { Upper } \\
\text { Bound }\end{array}$ \\
\hline 1 & (Constant) & 5.861 & 6.668 & & .879 & .387 & -7.819 & 19.542 \\
\hline & Metode & .958 & .118 & .843 & 8.152 & .000 & .717 & 1.200 \\
\hline
\end{tabular}

Berdasarkan table di atas, ternyata terdapat pengaruh yang kuat antara Metode Pembelajaran Terhada Akhlak Siswa MTs.Ma'arifRoudlotut-Tholibin. Hal ini di tunjukan oleh nilai t-hitung $(0,843)>t$-tabel dengan $\mathrm{df}=29$ baik dalam taraf signifikan $5 \%$ ataupun $1 \%$, sehingga variable Metode Pembelajaran berpengaruh Terhadap Akhlak Siswa MTs.Ma'arifRoudlotutTholibin.Perhitungan di atas juga memperlihatkan hubungan linier antara variable pengaruh Metode Pembelajaran Terhada Akhlak Siswa MTs.Ma'arifRoudlotut-Tholibin, dengan persamaan regresi $\hat{Y}=5,861+0,958 X_{2}$ yang menunjukan bahwa setiap kenaikan satu unit sekor atau item proses Metode Pembelajaran akan menyebabkan kenaikan kebiasaan Akhlak Siswa MTs.Ma'arifRoudlotut-Tholibin sebesar $(0,958)$ pada konstanta 5,861.Adapun 
besarnya pengaruh pengaruh Metode Pembelajaran Terhada Akhlak Siswa MTs.Ma'arifRoudlotut-Tholibin adalah 71,1\%.

Gambar. 4.4

Histogram Pengaruh Metode PembelajaranTerhadap Akhlak Siswa

Histogram

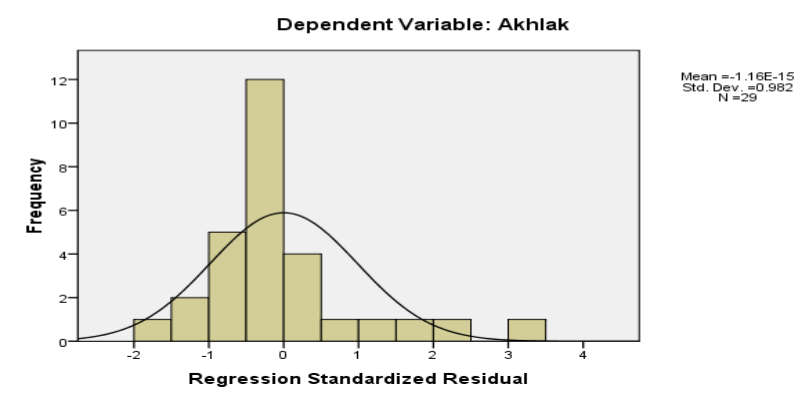

Gambar. 4.5

Plot Sebaran Pengaruh Metode Pembelajaran Terhadap Akhlak Siswa

Normal P-P Plot of Regression Standardized Residual

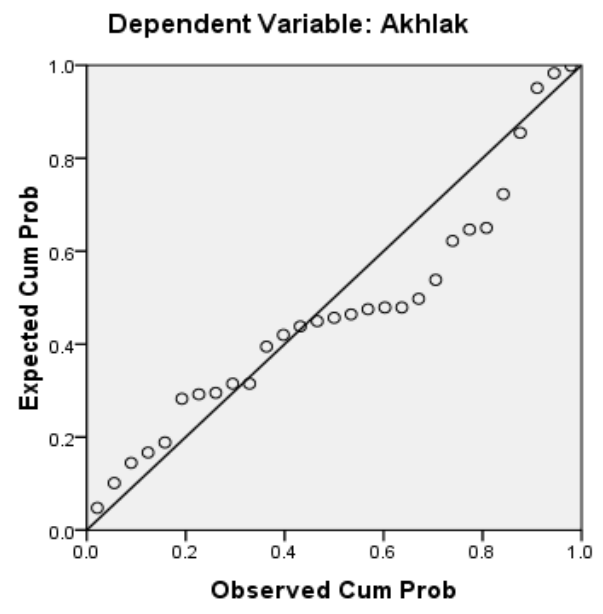

Pengaruh Secara Bersama-sama antara Teknik Motivasi Guru dan Metode Pembelajaran Terhadap Akhlak Siswa MTs.Ma'arifRoudlotut-Tholibin.

Hipotesis yang berbunyi "Ada pengaruh Teknik Motivasi Guru dan Metode Pembelajaran Terhadap Akhlak Siswa MTs.Ma'arifRoudlotut-Tholibin.". Model pengaruh Teknik Motivasi Guru dan Metode Pembelajaran Terhadap Akhlak 
FITRAH Jurnal Kajian Ilmu-ilmu Keislaman

Vol. 04 No. 2 Desember 2018

Siswa MTs.Ma'arifRoudlotut-Tholibin.dinyatakan dalam bentuk persamaan regresi $\hat{\mathrm{Y}}=6.059+0,804\left(\mathrm{X}_{1}\right)+0,179\left(\mathrm{X}_{2}\right)$.Uji pengaruh dan linieritas persamaan regresi.

Tabel 4.22

Uji Pengaruh Teknik Motivasi Guru dan Metode Pembelajaran terhadapAkhlak Siswa MTs.Ma'arifRoudlotut-Tholibin

\begin{tabular}{|c|c|c|c|c|c|c|c|c|c|}
\hline \multirow[b]{2}{*}{ Model } & \multirow[b]{2}{*}{$\mathrm{R}$} & \multirow[b]{2}{*}{$\begin{array}{c}\mathrm{R} \\
\text { Square }\end{array}$} & \multirow[b]{2}{*}{$\begin{array}{c}\text { Adjusted R } \\
\text { Square }\end{array}$} & \multirow[b]{2}{*}{$\begin{array}{l}\text { Std. Error of } \\
\text { the Estimate }\end{array}$} & \multicolumn{5}{|c|}{ Change Statistics } \\
\hline & & & & & $\begin{array}{l}\text { R Square } \\
\text { Change }\end{array}$ & F Change & df1 & df2 & $\begin{array}{l}\text { Sig. F } \\
\text { Change }\end{array}$ \\
\hline 1 & $.901^{\mathrm{a}}$ & .811 & .797 & 3.680 & .811 & 55.863 & 2 & 26 & .000 \\
\hline \multicolumn{10}{|c|}{ a. Predictors: (Constant), Metode, Motivasi } \\
\hline \multicolumn{10}{|c|}{ b. Dependent Variable: Akhlak } \\
\hline
\end{tabular}

Berdasarkan tabel summary $(\mathrm{R})$ yang secara simultan atau bersama-sama antara variabel Teknik Motivasi Guru dan Metode Pembelajaran terhadap Akhlak Siswa diperoleh nilai $r$ sebesar 0,901 ( $r=0,901)$. Hal ini menunjukan bahwa ketiga variabel memiliki pengaruh yang kuat positif. Sedangkan kontribusi yang diberikan adalah 79,7\%.

Tabel 4.23

Uji Pengaruh Teknik Motivasi Guru dan Metode Pembelajaran Terhadap Akhlak Siswa MTs.Ma'arifRoudlotut-Tholibin

\begin{tabular}{llrrrrr}
\hline \multicolumn{7}{c}{ ANOVA $^{\mathbf{b}}$} \\
Model & Sum of Squares & Df & Mean Square & F & Sig. \\
\hline 1 & Regression & 1512.726 & 2 & 756.363 & 55.863 & $.000^{a}$ \\
& Residual & 352.032 & 26 & 13.540 & & \\
& Total & 1864.759 & 28 & &
\end{tabular}

a. Predictors: (Constant), Metode, Motivasi

b. Dependent Variable: Akhlak

Berdasarkan tabel anova di atas, nilai Fhitung adalah sebesar 55,863 dengan demikian nilai Fhitung jika dibandingkan dengan nilai $F_{\text {tabel }}$ lebih yakni 55,863>0,388 dan 0,496 baik untuk taraf sig. 0,05 maupun 0,01. Sehingga model regresi linear berganda (Teknik Motivasi Guru, Metode Pembelajaran dan Akhlak Siswa) dari 
kedua variabel bebas (Teknik Motivasi Guru dan Metode Pembelajaran) dapat digunakan untuk memprediksi tingkat pengaruhnya terhadap akhlak.

Tabel 4.24

Uji Pengaruh Teknik Motivasi Guru dan Metode Pembelajaran terhadap Akhlak Siswa MTs.Ma'arifRoudlotut-Tholibin

\begin{tabular}{|c|c|c|c|c|c|c|}
\hline \multirow{2}{*}{\multicolumn{2}{|c|}{ Model }} & \multicolumn{2}{|c|}{$\begin{array}{c}\text { Unstandardized } \\
\text { Coefficients }\end{array}$} & \multirow{2}{*}{$\begin{array}{l}\text { Standardized } \\
\text { Coefficients } \\
\text { Beta }\end{array}$} & \multirow[b]{2}{*}{$\mathrm{t}$} & \multirow[b]{2}{*}{ Sig. } \\
\hline & & B & Std. Error & & & \\
\hline 1 & (Constant) & 6.059 & 5.493 & & 1.103 & .280 \\
\hline & Motivasi & .804 & .217 & .755 & 3.713 & .001 \\
\hline & Metode & .179 & .231 & .158 & .775 & .445 \\
\hline
\end{tabular}

a. Dependent Variable: Akhlak

Berdasarkan table coefisien di atas, menunjukan bahwa model persamaan regresi linear berganda untuk memperkirakan Akhlak Siswa yang dipengaruhi oleh Teknik Motivasi Guru dan Metode Pembelajaran adalah $\hat{Y}=6.059+$ $0,804\left(X_{1}\right)+0,179\left(X_{2}\right)$ yang ditunjukan dengan nilai koefisien pada tabel diatas, yaitu nilai constan sebesar 6,059 dan coefisien motivasi dan metode sebesar 0,804 dan 0,179 .

Bentuk Kurva antara Pengaruh Secara Bersama-sama antara Teknik Motivasi Guru dan Metode Pembelajaran Terhadap Akhlak Siswa MTs.Ma'arifRoudlotut-Tholibin

Gambar. 4.6

Histogram Uji Pengaruh Teknik Motivasi Guru dan Metode Pembelajaran TerhadapAkhlak Siswa MTs.Ma'arifRoudlotut-Tholibin

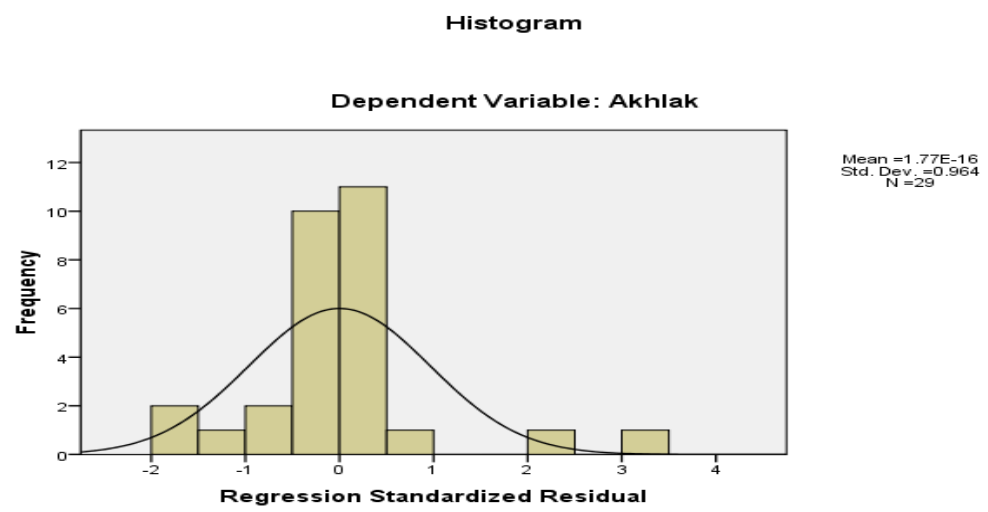


FITRAH Jurnal Kajian Ilmu-ilmu Keislaman

Vol. 04 No. 2 Desember 2018

Gambar. 4.7

Histogram Uji Pengaruh Teknik Motivasi Guru dan Metode Pembelajaran TerhadapAkhlak Siswa MTs.Ma'arifRoudlotut-Tholibin

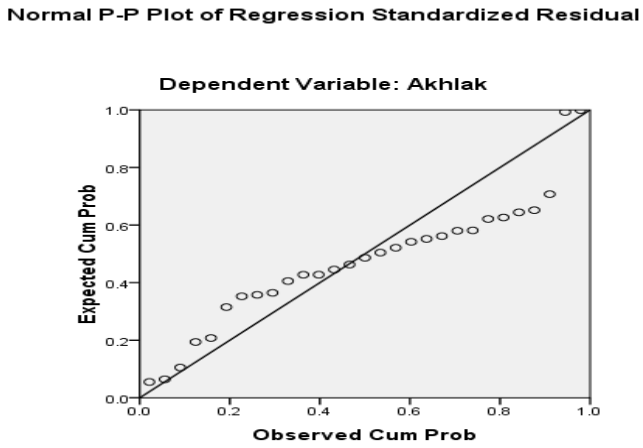

Kurva menunjukkan bahwa ada pengaruh Teknik Motivasi Guru dan Metode Pembelajaran Terhadap Akhlak Siswa MTs. Ma'arif Roudlotut-Tholibin adalah $79,7 \%$.

\section{PENUTUP}

Berdasarkan hasil pembahasan mengenai pengaruh teknik motivasi dan Metode Pembelajaran terhadap Akhlak Siswa MTs.Ma'arifRoudlotut-Tholibin maka dapat ditarik beberapa kesimpulan sebagai berikut :

a. Ada pengaruh Teknik Motivasi Guru terhadap Akhlak Siswa MTs.Ma'arifRoudlotut-Tholibin. Pada Pembahasan memperlihatkan hubungan linier positif yang kuat antara variable Teknik Motivasi Guru terhadap Akhlak Siswa MTs.Ma'arifRoudlotut-Tholibin, dengan persamaan regresi $Y=7,866+0,957$ X1. Adapun besarnya pengaruh Teknik Motivasi Guru terhadap Akhlak Siswa adalah 80,7\%.

b. Ada pengaruh Metode Pembelajaran terhadap Akhlak Siswa MTs.Ma'arifRoudlotut-Tholibin. Pembahasan di atas juga memperlihatkan hubungan linier antara variable pengaruh Metode Pembelajaran terhadap Akhlak Siswa MTs.Ma'arifRoudlotut-Tholibin, dengan persamaan regresi $\hat{Y}=$ $5,861+0,958 X_{2}$.Adapun besarnya pengaruh Metode Pembelajaran Terhada Akhlak Siswa MTs.Ma'arifRoudlotut-Tholibin adalah 71,1\%.

c. Ada pengaruh variable Teknik Motivasi Guru dan Metode Pembelajaran terhadap Akhlak Siswa secara bersam- sama diMTs.Ma'arifRoudlotutTholibin. Perhitungan di atas juga memperlihatkan hubungan linier antara variable Teknik Motivasi Guru dan Metode Pembelajaran Terhadap Akhlak Siswa MTs.Ma'arifRoudlotut-Tholibin, dengan persamaan regresi $\hat{Y}=6,059+$ $0,804\left(X_{1}\right)+0,179\left(X_{2}\right)$. Adapun besarnya pengaruh Teknik Motivasi Guru dan Metode Pembelajaran terhadap Akhlak Siswa MTs.Ma'arifRoudlotut-Tholibin adalah $79,7 \%$. 


\section{DAFTAR PUSTAKA}

Al- Toumy Al Syabany, Omar Mohammad. Falsafah Pendidikan Islam. (terjemahan Hasan Langgulung dari Falsafah al- Tarbiyah al- Islamiyyah), cet. 2. Jakarta: Bulan Bintang, 1979.

Ali, Muhammad Daud. Pendidikan Agama Islam. Jakarta: PT. Raja Grafindo Persada, 2011.

A.M, Sardiman. Interaksi \& Motivasi Belajar Mengajar. Jakarta: Raja Grafindo Persada, 2011.

Anwar, Rosihon. Akidah Akhlak. Bandung: Pustaka Setia, 2008.

Arikunto, Suharsimi. Prosedur Penelitian: Suatu Pendekatan Praktik. Jakarta: Rineka Cipta, 2013.

B. Uno, Hamzah. Teori Motivasi dan Pengukurannya. Jakarta: Bumi Aksara, 2006.

Daradjat, Zakiah. Metodik khusus pengajaran agama Islam. Jakarta: Bumi Aksara, 1995.

Davis, James R. Teaching Strategies for the College Classroom. Westview Press, 1976.

Departemen Agama RI. Al-Qur'an dan Terjemahnya. Bandung: CV Penerbit J-ART, 2005.

DEWAN PERWAKILAN RAKYAT REPUBLIK INDONESIA, dan PRESIDEN REPUBLIK INDON. Undang-undang Republik Indonesia Nomor 20 tahun 2003 tentang Sistem Pendidikan Nasional. Bandung: Fokus Media, 2006.

Fathurrohman, Pupuh, dan M. Sobry Sutikno. Strategi Belajar Mengajar Melalui Penanaman Konsep Umum \& Konsep Islami. Bandung: Refika Aditama, 2010.

Gulo, W. Metodologi Penelitian. Jakarta: PT. Gramedia Widia Sarana Indonesia, 2002.

Majid, Abdul. Belajar dan Pembelajaran Pendidikan Agama Islam. Hasil penelitian Heyneman Dan Loxley. Bandung: PT Remaja Rosdakarya, 2012.

Muhaimin. Pengembangan kurikulum pendidikan agama Islam: di sekolah, madrasah, dan perguruan tinggi. Jakarta: RajaGrafindo Persada, 2005. 
FITRAH Jurnal Kajian Ilmu-ilmu Keislaman

Vol. 04 No. 2 Desember 2018

Nasih, Ahmad Munjin, dan Lilik Nur Kholidah. Metode dan Teknik Pembelajaran Pendidikan Agama Islam. Bandung: PT.Refika Aditama, 2013.

Nasution, S. Metode Research. Jakarta: Bumi Aksara, 2000.

Nizar, Samsul. Filsafat Pendidikan Islam, Pendekatan Historis, Teoritis dan Praktis. cet. ke-1. Jakarta: Ciputat Pers, 2002.

Ramayulis, H. Metodologi pendidikan agama Islam. Jakarta: Kalam Mulia, 2010.

Rasdijanah, Andi. Butir-Butir Pengarahan Dirjen Bimbaga Islam pada Acara Pelatihan Peningkatan Wawasan Ilmu Pengetahuan dan Kependidikan Bagi Dosen Pendidikan Agama Islam padaPerguruan Tinggi Umum. Bandung: Dirjen Bimbingan Islam, 1995.

Saebani, Beni Ahad, dan Abdul Hamid. Ilmu Akhlak. Bandung: Pustaka Setia, 2010.

Saebani, Beni Ahad, Abdul Hamid, dan M. Yatimin. Studi Akhlak Dalam Perspektif Islam. Jakarta: Amzah, 2007.

Siregar, Syofian. Statistik Parametrik untuk Penelitian Kuantitatif. Jakarta: Bumi Aksara, 2013.

Sudijono, Anas. Pengantar Statistik Pendidikan. Jakarta: Rajawali Pers, 2010.

Sugiyono. Metode Penelitian Pendidikan, Pendekatan Kualitatif, Kuantitatif, dan RED. Bandung: Alfabeta, 2009.

Suryabrata, Sumadi. Metode Penelitian. Jakarta: Raja Grafindo Persada, 2008.

Syafaat, TB. Aat. Peranan pendidikan Agama Islam dalam mencegah kenakalan remaja (juvenile deliquency). Jakarta: Rajawali Pers (Rajagrafindo Persada), 2008. 